\title{
Diversity and Opportunity in a Good City Making, Learning from Informal Settlement in Yogyakarta-Indonesia
}

\author{
Muhammad Nelza Mulki lqbal
}

Muhammad Nelza Mulki Iqbal, ST, Indonesian Endowment Fund For Education,

\begin{abstract}
The Greek thinker Aristotle ever tried to explain cities phenomenon by mentioning that a good life can be founded in the togetherness of city living. Nevertheless, today's fact there is no city has ever meant the good life for all its inhabitants. It becomes harder and harder to define a good life inside the city, as well as looking what makes a good city in current perspective. Cities are now seen at best as a great social problem and at worst as utopian city solution that yet never come. That makes sense that the concept of making good city is debatable, and somehow it is very subjective.

Starting with an explanation of the period when a good city notion emerged, this essay will try to analyze in a very brief manner the discourses between physical and nonphysical strategies to develop a good city notion. Afterwards, it will be extended to the role of opportunity to build a future good city. The opportunity will be in line with the concept of the right to the city, which originally based on Henri Lefebvre's Theory (Lefebvre, 1996). Staying back to the musing between what is good and what is bad, this essay is trying to investigate what is reasoning behind good or bad and how to solve it. Then, it will be navigated to how people can deal with the bad condition of the city and solving their problem as a part of their right.

The notions of a good city, however, belong to the residents. What city needs the most was a most intricate and close-grained diversity of uses that give each other constant mutual supports (Jacobs, 1961). The cases of Kampung Code in Yogyakarta, which was the winner of Aga Khan Award for Architecture in 1992 will be highlighted to be an example of how people are dealing with their bad condition, struggling on their right and taking the opportunity given.
\end{abstract}

\section{Between Physical and Non-Physical Strategies}

The long history of making a good city has been emerged since the end of 19th century and the beginning of 20th century. These discourses related to the bad city condition in European and Northern American society including mental and physical (Fainstein, 2000). It then raised planner as a visionary expert to envision future good city. They believed that notion about the good city could be taken from imagining ideal city through its physical regularity, neatness, and beautify of the city. For "professionals and expertise", it was urgent to make a new order of the city to come up with all social conflicts and miseries. Reformation of physical environment was believed to solve city and life society problems (Fishman, 1996). The earliest era of planning activity towards the prospecting good city was guided by determinism of physical environment philosophy. Its subject matters designed city, parks, boulevards, and new settlements, among others. 
One of the most prominent literature of a good city is The Good City Form (Lynch, 1981), that was written by the most influential thinkers in contemporary urban planning, Kevin Lynch. An urban environment is a complex system of interaction between people and surrounding objects. He mentioned that achieving good city will require five performance dimensions such as vitality, sense, fit, access, and control, and two meta-criteria including efficiency and justice. He then defined the legibility of the cityscape as the entry point with which its parts can be recognized and organized into an obvious pattern or symbolic manner. Therefore, he emphasized imageability as the feature of a physical object which can view as vivid images towards good city meant to be. His solution about making a good city was clear, by using a strong physical recognition that recognized by city inhabitants.

He pointed out five elements of legibility; path, edge, node, landmark, and district. Through visualizing urban environment, analysis of good city will be guided in the syntax process of cognitive mapping by the user of the urban environment. It relates to individual capacity for memorizing and retrieving information about a familiar environment (Sidadin, 2007). By understanding what revealed from the users, urban designer could create places that more satisfying, as people would be able to have clear and memorable as they might be wanted. It is true that Lynch's theory based on general normative theory through visualspatial characteristics, and in short we can conclude that the more imageable places, the more city users get satisfied. Even what is good can be traced through his judgements, hints, hierarchies, but it still not clearly enough and trigger further discussions.

In opposition with what Kevin Lynch proposed, more than 50 years ago Jane Jacobs, by her magnum opus The Death and Life American City (Jacobs, 1961), one of the most influencing urban discourse in the twentieth century. She challenged the discipline of urbanism and led them to a paradigm shift. Even she is coming from an activist background and having a lack professional architectural or planning qualification, but she can tease out debates on this subject and started a fundamental change in looking city problems. The book elaborated a highly critics of planners ideologies idea, like Howard's Garden City, Le Corbusier's Radiant City, and Burnham's Beautiful City.

She argued a beautiful way to look at the city not as a homogenous entity, but diverse conditions which make it alive. What city need most, she wrote, was a "most intricate and close-grained diversity of uses that give each other constant mutual support" (Jacobs, 1961). Jacob urged planners to eschew abstract models of the ideal city which she sarcastically collapse into a single paradigm entitled "radiant garden beautiful city". Instead, she exhorts them to look at the real city that people love and which is characterized by congestion, multiple interactions among strangers, short streets, and mixed uses (Susan, 2011).

She also reinforced that even the most powerful planner in many ways cannot resolve city problems while small groups can. They will be able to overcome their problem precisely in extraordinary and unpredictable solutions. Jacobs believes that the planner must no longer try, like Howard, Wright, and Le Corbusier once tried, to define the central goals of society and offer a unified plan for attaining them. For her, the city is already built; it can be renovated but never transformed (Fishman, 1996). She mentioned the capability of the city for providing something for everybody, only because, and only when they created by everybody. Cities are formed from organised complexities that are not simple and intertwined each other. The treating bad condition, such as slums, for Jacobs, was not just simply building vertical structures while horizontal structure will work better in city upgrading (Cannifee, 2012). The diversity of the city can stimulate individual and group creativity that will enhance social capital, economics, and spatial relations. 


\section{The Right to the City towards Diversity}

Understanding today's complexity of the city always relates to social and cultural diversity throughout the multicultural city. The multicultural city is the place of difference, otherness, fragmentation, splintering, multiplicity, heterogeneity, plurality and diversity (Sanderdock, 2002). That is the answer to the problem in current city planning towards a good city. It does not stop by recognising physically of the city, but it should be able to encourage people and support its diversity inside the city. It then will become a powerful movement to get closer to a good city meant to be.

Coming back to the notion of The Right to the City, Harvey notes that the right of the city is not only the right of the access that city embodies but a chance to re-develop and change the city more after the heart desire (Harvey, 2003). The right to the city through urban social movements will work with on-going struggles over who gets to shape the qualities of daily urban life. It involves two principal rights for urban inhabitants those are participation and appropriation. Further, the key of Lefebvre's notion is a decision making in the city (Purcell, 2002). In doing so, the right of the city will work with Lefebvre's notion of space, where he pointed out perceive, conceive and lived space in the production of space (Lafebvre, 1991).

An opportunity in delivering the decision to overcome city problems will be clearly visible and reliable to the people who perceive, conceive, and lived in their everyday life. Something familiar closes, and intimate due to its relation and experience that conscious or unconsciously repeated and cannot be divided into people daily life. Moreover, it is also notable that space experience will be different and diverse from one to each other. It tends to be subjective experiences depend on personal and community interpretation. Even we cannot avoid the reality that something every day for one person will be possibly different with others people's everyday life, but in the scale of community living that already intertwined for a long time the notion of everyday life can be a starting point to recognize problems and solutions.

Furthermore, the connection between all these narratives is linking backs again to the question what makes a good city. In my opinion, the right of the city should be sharpened to the right of the freedom opportunity in making a decision. People in the cities with their diversity will have an opportunity to choose whatever they want. They may be living outside the condition of normal life. They probably in a condition that never deployed as a good imageable as a mostly people want. But the city is shaped more by forces of daily life than formal design and official plans that in a certain condition tends to be a utopia. Urban design and planning have traditionally been involved with the creation of permanent or static in the implementation of infrastructure or designing open spaces. However, in reality, it is the kinetic-diverse-fabric people that ground reality in a very personal engagement.

\section{Non-Plan Planning and Freedom of Opportunity}

Assuming that every part of the city will be able to have their right to develop the city, it emerged the question about the role of professional planning in making a good city. It also reminds me about Non-Plan: an experiment in freedom which published in 1969 by Peter Hall (Geographer and Planner), Reyner Banham (Architecture Historian), Cedric Price (Architect), and Paul Barker (Writer) in the social magazine New Society. They wrote extensive text on the evolution of hierarchical order that influenced by Carl Jung's Collective Unconsciousness. One of the most prominent examples is Collage City suggested by Colling Rowe and Fred Koetter (Rowe and Coetter, 1987). Relevant to the non-linear notion of reinvigorated design practice previously known as Collage art or painting. Collage City rejects the concept of "total planning" and "total design". Reconsidering historical urban fabric, 
Rowe and Koetter put forward collage as the means of accommodating the whole range of utopian miniatures instead of forcing single hegemonic grand utopia (Swadiansa, 2012). This visionary concept has become more contextual over time and received much support in urbanism discourses.

Cedric Price saw the city as a non-cohesive structure but constantly reorganizing and rearranging itself through urban processes. Non-Plan explored ways to embrace people by avoiding planning bureaucracy, and let people shape their environment. Favelas are one of the examples of non-planning movement that built by the self-organizing community in Rio Di Janeiro, Brasil. Most of Favelas began in the 1970s due to the housing crisis that forced poor to build their house outside center Rio. In the Favelas, people participate to non-plan development through self-help housing, water and electricity installation, and also its construction. Non-plan movement is the proof what Foucault ever mentioned "leave people in the slum, thinking that they can simply exercise their rights there" (Boano, 2011; Foucault, 2003).

Another evidence was driven by John F.C Turner, through his investigation of housing development in Peru, Housing by people (Turner, 1976). Among 1957 to 1965 he tried to compare housing development for society in Lima that initiated by the government and spontaneous settlement by people. He mentioned the issue of autonomy and heteronomy in human settlement and housing. After investigating both of them, there are no significant different qualities between standard housing by the government and spontaneous housing that previously recognized as a squatter. He also pointed out legitimation of the land that previously forbidden by the government could escalate people desire to build their house. Through this investigation, Turner concluded that people even poor people will have their own power and abilities to build their settlement as long as they have an opportunity to do so.

\section{From Non-Plan Planning to Professional Mediation, Learning from Kampung Code, Yogyakarta-Indonesia}

Talking about the urban solution in cities, especially about making good city is not just about buildings and infrastructure with various used or shared among residents, not just the specific public spaces identified through a checklist of green areas, square, and facilities. Rather, the sense of making good city lies more in the use of space, civic culture and infrastructure as a process that modulates the diverse and frequently contradictive with everyday urban life. The work of opportunity can be envisioned as a matter of reoccupying particular city spaces and using that occupation as a means of experimenting with different ways of accelerating concrete sense of inclusiveness the inhabitants. The important thing for having an opportunity to city inhabitants is its ability to build collaboration action and incrementally solve their bad condition.

Kampongs in Indonesia have become a key feature of the city (Ford, 1993), it is unorganized, unstructured and consist of an informal settlement in relation to the broader socio-economic system. Kampong is also influenced by trade and commercial goods, and generally has high population density and better education. It is simply traditional, spontaneous, risky, and diverse settlement in the urban area (Sihombing, 2004). In many cities in Indonesia, mostly Kampongs recognized as an informal and illegal settlement, or even dangerous due to its risky location. It emerges for a long time in an illegal government land, near riverbanks, or close to the railway. That is the reason it tends to be evicted and becomes a contested arena in the city. 
Kampong Code located in Yogyakarta, Indonesia and it was used to be a slum area and risky settlement. Inhabitants in Code lived under Gondolayu Bridge and on near riverbanks of Code River. No one knows who own the land in Kampong Code, It became massive settlements with the lack of quality and often got trouble when rainy season. In 1984, the government planned to relocate this region as a part of city greenbelt program and river normalization. It raised highly refusal from its inhabitants as well as an urban activist. One of the main actors was Romo Mangunwijaya, a priest, and architect who criticized the government by mentioning that green belt in Indonesian's river is truly different to what meant to be a green belt in Berlin, New York, or Amsterdam. It has been proven in a decade that a place indicated by a green belt closely to criminality, prostitution, and waste problems. Settlements that exist on the line of green belt helped a lot to overcome the problems, let society keep the riverbanks and start a green kampong as a better solution than eviction (Kudori, 2002).

After a series of tensions, mediation and including fasting movement that Romo Mangunwijaya did, Kampong Code finally got the opportunity to stay in. In 1983, Romo Mangunwijaya, the social community of Kampong Code, academia, and volunteers launched the area's physical reconstruction and community's mental transformation and gradually converted Kampong Code into a distinctive zone and artistic dwelling place. The humanity approach that Romo Mangunwijaya did can make a better and healthier place to live in. Romo Mangunwijaya also changed people's view of life with a better opportunity for living. Along with Pondok Rakyat Foundation, he educated people to manage the money. Kampung Code switched to convenient, attractive, and peaceful location. It attracted many scholars to do a research inside, and attract tourism to know deeply about community city upgrading in Kampung Code. In 1992, Kampong Code received an International Award named Aga Khan Award for Architecture for structural design. It becomes a well-known precedent of city and community developing to deal with the bad condition.

\section{Conclusion and Beyond}

The essay stated in a position that making a good city cannot only be taken from just measuring physical strategies of the city. It is also not just leaving non-physical potential of the society and let it encounters their solution. Even, non-plan planning is obviously can work out in the reality of the society. However, the role of professional in urbanism also can push out people potential to confront with the problems. As a contested area, the city will need ideas with satisfying material needs and resolving to compete for social requirements through a process of active participation by the occupants and mediation of professional (Boano, 2011).

The case study examples have shown that how the opportunity was given can be converted into major changes over the problems. It changed what in ninetieth and twentieth recognized as a bad condition; slums, irregular, informal, dirty and risky into harmony place with various possibility potential afterward. In term of the right of the city, Lefebvre argued that the right of the city should modify, concretize, and make more practical the right of the citizen as an urban dweller and user of multiple services (Purcell, 2002). Giving an opportunity to the people to deal with their problem can provoke great ideas for the city. Inhabitants in Kampong code firstly come without money, skills and knowledge. They know how to survive for their life, even they do not know why they have been settled there and how to get out from its situation. They have several good habits like hard work and commonality, but something bad such as gambling. Encountering poor people does not mean to give them something that makes them dependence on, but open the possibility to solve their problem to reach better quality life in the better social equity (Khudori, 2002). 
Furthermore, looking for a good city notion cannot be simply achieved in a singular thing. Freedom of opportunity can be achieved as long as the right of the city can be fulfilled by the state. The major driven power of making good city is the state through its interventions and provisions. People in the bottom line, as well as professionals, have been proven the possibility of treating bad cities condition. Lastly, my deep intention through this essay is to broaden the current perspective in good city making and pointed out freedom of opportunity to tackle city problem towards a good city. 


\section{References}

Fainstein, Susan S., 2005: Cities and Diversity. Should We Want It? Can We Plan For It. Urban Affair Review, Vol. 41 No. 1: 3-19.

Fishman, Robert. 1977. Urban Utopias in The Twentieth Century. New York: Basic Books, Inc., Publisher

Lynch, Kevin. 1981. Good City Form, MIT Press

Jacobs, Jane. 1961. The Death and Life of Great American Cities. New York: Random House.

Canifee, Eamonn. 2011. Review Jane Jacobs: The Death and Life of Great American City. [online] Available at http://architectureandurbanism.blogspot.co.uk/2012/03/janejacobs-death-and-life-of-great.html [Accessed 25 November 2011]

Kelbaugh, Douglas. 2004. Preface. Everyday Urbanism Michigan Debates on Urbanism. New York: Art Press

Harvey, D. 2003. The Right to the City. International Journal of Urban and Regional Research, 27(4), 939-941

Purcell, M. 2002. Excavating Lefebvre: The right to the city and its urban politics of the inhabitant. Geojournal, 58, 99-108

Lefebvre, H. 1991. The production of space (D. Nicholson-Smith, Trans). Oxford: WileyBlackwell

Rowe C. and Koetter F. (1987), Collage City, Cambridge, MA: MIT Press

Swadiansa, E. 2012. "From Urban Studies to Urban Architecture: Critiques on the Use of Eurocentric Theories in Shaping the Emerging Cities" in Kudori,D., \& Kamino Y. (ed). Towards a Sustainable Ecology: Global Challenge and Local Responses in Africa and Asia. Paris: GRIC Le Havre Universite, 235-243.

Boano, C. 2011. The Frontlines of Contested Urbanism Mega-Project and Mega-Resistances in Dharavi. Jurnal of Developing Societies 27, 3\&4. 295-326.

Turner, John F. C. 1976. Housing by People: Towards Autonomy in Building Environments. New York: Pantheon Books.

Sihombing, A. 2004. The transformation of Kampung Kota; symbiosis between kampung and kota, a case study from Jakarta. Department of Architecture, University of Indonesia 